\title{
Synthesis and Fluorescence Properties of Europium - Substituted Lanthanum Polyphosphates
}

\author{
Hiroaki Onoda $^{1} \&$ Takehiro Funamoto $^{1}$ \\ ${ }^{1}$ Department of Informatics and Environmental Science, Kyoto Prefectural University, Shimogamo Nakaragi, \\ Sakyo, Kyoto, Japan \\ Correspondence: Hiroaki Onoda, Department of Informatics and Environmental Science, Kyoto Prefectural \\ University, Shimogamo Nakaragi, Sakyo, Kyoto 606-8522, Japan. Tel: 81-75-703-5653. E-mail: \\ onoda@kpu.ac.jp
}

Received: October 8, 2012 Accepted: November 10, 2012 Online Published: December 5, 2012

doi:10.5539/jmsr.v2n1p75 URL: http://dx.doi.org/10.5539/jmsr.v2n1p75

\begin{abstract}
Europium-substituted lanthanum polyphosphates (Eu; 0, 1, 2, 3, 4, 5, and $10 \mathrm{~mol} \%$ ) were prepared from lanthanum nitrate, europium nitrate, and sodium polyphosphate solutions. The obtained phosphates were estimated using XRD patterns, TG-DTA curves, SEM images, and particle size distributions. The fluorescence spectra were estimated as functional properties of these phosphate materials. The obtained samples crystallized by heating at $600^{\circ} \mathrm{C}$. Lanthanum polyphosphates were stable from 600 to $850^{\circ} \mathrm{C}$. The $5 \mathrm{~mol} \%$ europium-substituted lanthanum polyphosphate showed a strong peak at $615 \mathrm{~nm}$.
\end{abstract}

Keywords: lanthanum polyphosphate, europium, XRD patterns, TG-DTA curves, fluorescence

\section{Introducation}

Phosphates are transformed to other forms of phosphates by hydrolysis and dehydration reactions at elevated temperatures (Averbuch-Pouchat \& Durif, 1996, Hammas et al., 2010). Polyphosphate and ultraphosphate are included in a group of condensed phosphates. Polyphosphate has a chain structure in which the $\mathrm{PO}_{4}$ unit shares two oxygen atoms and ultraphosphate has a network structure. Formation of these condensed phosphates was affected by the ratio of phosphorus/cation, heating temperature, time, atmosphere, and so on (Raynaud et al., 2002; Boonchom et al., 2008; Rathan \& Govindaraj, 2010). Therefore, it was difficult to obtain a high yield of the condensed phosphates. Consequently, orthophosphate has been investigated for various uses, but condensed phosphates have been little studied. Orthophosphate materials have been used for ceramic materials, catalysts, fluorescent materials, dielectric substances, metal surface treatment, detergent, food additives, fuel cells, pigments, etc. (Shuetz \& Caruso, 2002; Meiser et al., 2004). The condensed phosphates have different properties from those of orthophosphates and can therefore be used as novel functional materials (Onoda et al., 2002, Onoda et al., 2005; Briche et al., 2010; Onoda et al., 2010).

Rare-earth phosphates have a high melting point and large specific surface area in phosphate materials (Rajesh et al., 2007; Onoda et al., 2008). Rare-earth orthophosphates, which are the main component of rare-earth ores, are stable phosphate groups in acidic and basic solutions. Their resistance in acidic and basic solutions was developed into other phosphate materials (Onoda et al., 2007). Moreover, rare earth elements are important in fluorescence properties. Especially, the addition of europium indicated strong fluorescence in materials of various kinds (Bettinelli et al., 2012). In previous work, the europium-substituted lanthanum condensed phosphates were synthesized from lanthanum oxide, europium oxides, and phosphoric acid (Onoda \& Funamoto, 2012). The europium-substituted lanthanum polyphosphate and ultraphosphate were more suitable materials than orthophosphate for red luminescence. Therefore, in this work, lanthanum polyphosphates were studied as a host material. In the previous work (Onoda \& Funamoto, 2012), lanthanum polyphosphates were synthesized by solid state reaction. The major synthetic processes of lanthanum polyphosphate were the folling methods.

For the syntheses of inorganic phosphates, there are some methods, one is based on the solid state reaction, another one is on the cation exchange reaction in aqueous solution (Onoda \& Okumoto, 2011). The method by the solid state reaction had some merits to be easy to form condensed phosphate and to control the molar ratio of cation/phosphorus, on the other hand, had a demerit to be difficult to keep the homogeneity of materials (Onoda et al., 2002). On the other hand, the preparation of transition metal phosphate in aqueous solution had an 
advantage to obtain the homogenized materials and various kinds of metal phosphates. However, it had a weak point to be difficult to control the molar ratio of cation/phosphorus (Onoda et al., 2008). The synthetic method had much influence on the properties of phosphate materials (Onoda \& Okumoto, 2011). There are some cases that the phosphate prepared in aqueous solution has the different properties with the phosphate synthesized in solid state reaction.

For this study, the europium-substituted lanthanum polyphosphates were synthesized from lanthanum nitrate, europium nitrate, and sodium polyphosphate solutions. The respective chemical compositions, particle shapes and size distributions of the obtained products were evaluated. Furthermore, these phosphate materials were studied for their fluorescence properties.

\section{Experimental}

Sodium polyphosphate, $\mathrm{NaPO}_{3}$, was synthesized by heating sodium di-hydrogen phosphate, $\mathrm{NaH}_{2} \mathrm{PO}_{4}$ at $700^{\circ} \mathrm{C}$ for 2 hours, and then by quenching. This salt, sodium polyphosphate, was known to be inorganic phosphate polymer that has about 110 of polymerization number (Miyajima et al., 1996). $0.1 \mathrm{~mol} / 1$ of lanthanum nitrate solution $\left(\mathrm{La}\left(\mathrm{NO}_{3}\right)_{3}\right)$ was mixed with $0.1 \mathrm{P}-\mathrm{mol} / 1$ of sodium polyphosphate solution $\left(\mathrm{NaPO}_{3}\right)$ at mole ratios of $\mathrm{P} / \mathrm{La}=3$. The $1,2,3,4,5$, and $10 \mathrm{~mol} \%$ of lanthanum nitrate was substituted with europium nitrate $\left(\operatorname{Eu}\left(\mathrm{NO}_{3}\right)_{3}\right)$. All chemicals were of guaranteed reagents from Wako Chemical Industries Ltd. (Osaka, Japan) without further purification.

The respective chemical compositions of these thermal products were analyzed using X-ray diffraction (XRD) and Thermogravimetry-Differential Thermal Analysis (TG-DTA). X-ray diffraction patterns were recorded on a Rigaku MiniFlex X-Ray diffractometer using monochromated $\mathrm{CuK} \alpha$ radiation. TG and DTA curves were measured with a Shimadzu DTG-60A at a heating rate of $10^{\circ} \mathrm{C} / \mathrm{min}$ under air. The powder properties of thermal products at $200,400,600$, and $800^{\circ} \mathrm{C}$ were characterized by particle shape and size distribution. The particle shapes of phosphate powder were observed from scanning electron micrographs (SEM, JGM-5510LV; JEOL). Particle size distribution was measured with laser diffraction/scattering particle size distribution HORIBA LA-910. The fluorescence properties were measured using a luminescence spectrometer (LS55; Perkin-Elmer).

\section{Results and Discussion}

\subsection{Chemical Compositions and Powder Properties of Europium-substituted Lanthanum Polyphosphates}

Figure 1 shows XRD patterns of europium-substituted lanthanum polyphosphates (Eu; $5 \mathrm{~mol} \%$ ) heated at several temperatures. Samples heated at 200 and $400^{\circ} \mathrm{C}$ were amorphous in XRD analyses (Figure 1 (a) and (b)). On the other hand, samples heated at 600 and $800^{\circ} \mathrm{C}$ had XRD peak patterns of lanthanum polyphosphate, $\mathrm{La}\left(\mathrm{PO}_{3}\right)_{3}$ (Figure 1 (c) and (d)). Because XRD patterns of lanthanum polyphosphates had no change by the substitution with europium, the europium cation was substituted to lanthanum site in lanthanum polyphosphate.

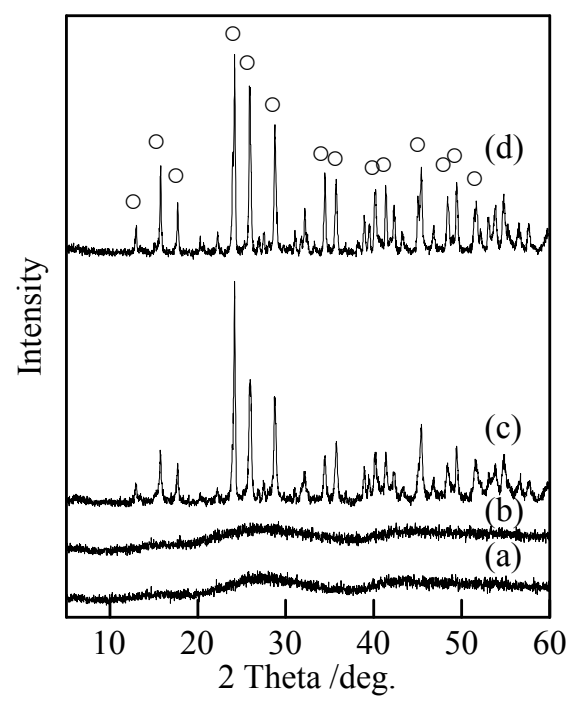

Figure 1. XRD patterns of samples (Eu; $5 \mathrm{~mol} \%$ ) heated at several temperatures, (a) $200^{\circ} \mathrm{C}$, (b) $400^{\circ} \mathrm{C}$, (c) $600^{\circ} \mathrm{C}$, and (d) $800^{\circ} \mathrm{C}, \circ, \mathrm{La}\left(\mathrm{PO}_{3}\right)_{3}$ 
Figure 2 portrays TG-DTA curves of samples prepared at 0 and $5 \mathrm{~mol} \%$ of europium-substitution. The endothermic peaks below $180^{\circ} \mathrm{C}$ in DTA curves were due to the volatilization of adsorbed and crystalline water. The weight loss was about $4 \%$ in TG curves of both samples (Eu; 0 and 5 mol\%). TG curves of both samples had about $6 \%$ of weight loss at $220-550^{\circ} \mathrm{C}$. At this temperature, the weak endothermic peak was observed in DTA curves. In preparation process, a part of sodium polyphosphate was decomposed to orthophosphate with water (following Equation (1)). The sodium orthophosphate was reacted with lanthanum nitrate, and the precipitate was obtained (Equation (2)). The lanthanum di-hydrogen orthophosphate was condensed to lanthanum polyphosphate at $220-550^{\circ} \mathrm{C}$ (Equation (3)).

$$
\begin{aligned}
\mathrm{NaPO}_{3}+\mathrm{H}_{2} \mathrm{O} & \rightarrow \mathrm{NaH}_{2} \mathrm{PO}_{4} \\
3 \mathrm{NaH}_{2} \mathrm{PO}_{4}+\mathrm{La}\left(\mathrm{NO}_{3}\right)_{3} & \rightarrow \mathrm{La}\left(\mathrm{H}_{2} \mathrm{PO}_{4}\right)_{3}+3 \mathrm{NaNO}_{3} \\
\mathrm{La}\left(\mathrm{H}_{2} \mathrm{PO}_{4}\right)_{3} & \rightarrow \mathrm{La}\left(\mathrm{PO}_{3}\right)_{3}+3 \mathrm{H}_{2} \mathrm{O}
\end{aligned}
$$

Because the weight loss in Equation (3) was about 4.2\%, the ratio of decomposition was enough high in sodium polyphosphate solution and the other phenomenon, for example, the volatilization of nitrate anion, also took place at this temperature. The exothermic peak at $589^{\circ} \mathrm{C}$ was shifted to $603^{\circ} \mathrm{C}$ with the europium-substitution. This exothermic peak was due to the crystallization of lanthanum polyphosphate. At over $800^{\circ} \mathrm{C}$, lanthanum polyphosphate decomposed to lanthanum orthophosphate losing phosphorus oxide in following Equation (4).

$$
\mathrm{La}\left(\mathrm{PO}_{3}\right)_{3} \rightarrow \mathrm{LaPO}_{4}+\mathrm{P}_{2} \mathrm{O}_{5}
$$

Lanthanum polyphosphate was stable from 600 to $850^{\circ} \mathrm{C}$ from TG-DTA curves. Therefore, thermal products from 600 to $850^{\circ} \mathrm{C}$ were expected for stable fluorescence materials.

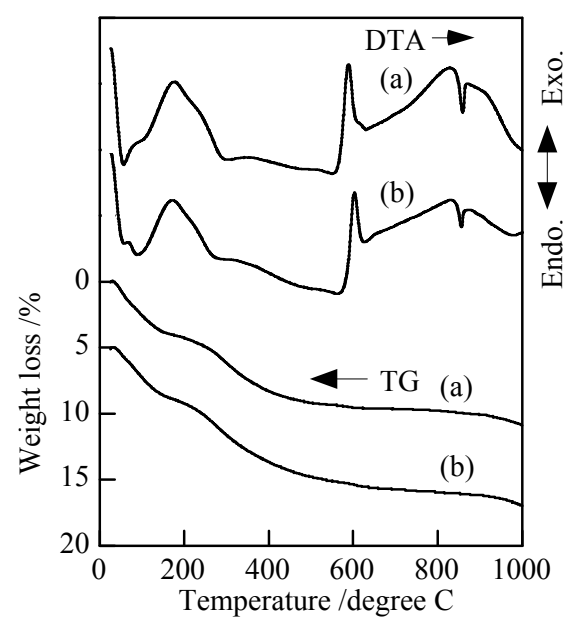

Figure 2. TG-DTA curves of samples, (a) Eu; $0 \mathrm{~mol} \%$, (b) $5 \mathrm{~mol} \%$

Figure 3 depicts SEM images of samples prepared at $5 \mathrm{~mol} \%$ of europium-substitution and then heated at various temperatures. All samples had no specified shape in spite of the europium ratio and heating temperatures. In previous work, the particles had a plane at samples synthesized by heating (Onoda \& Funamoto, 2012). The europium-substituted lanthanum polyphosphate had different particle shape from the synthetic methods. Figure 4 shows particle size distribution of samples (Eu; $5 \mathrm{~mol} \%$ ) heated at several temperatures. The particle size of samples was from 2 to $500 \mu \mathrm{m}$. Samples had smaller particle size by heating, because of the sintering effects. Lanthanum polyphosphate formed small densed particles by heating at high temperature with losing water and space in particles. 

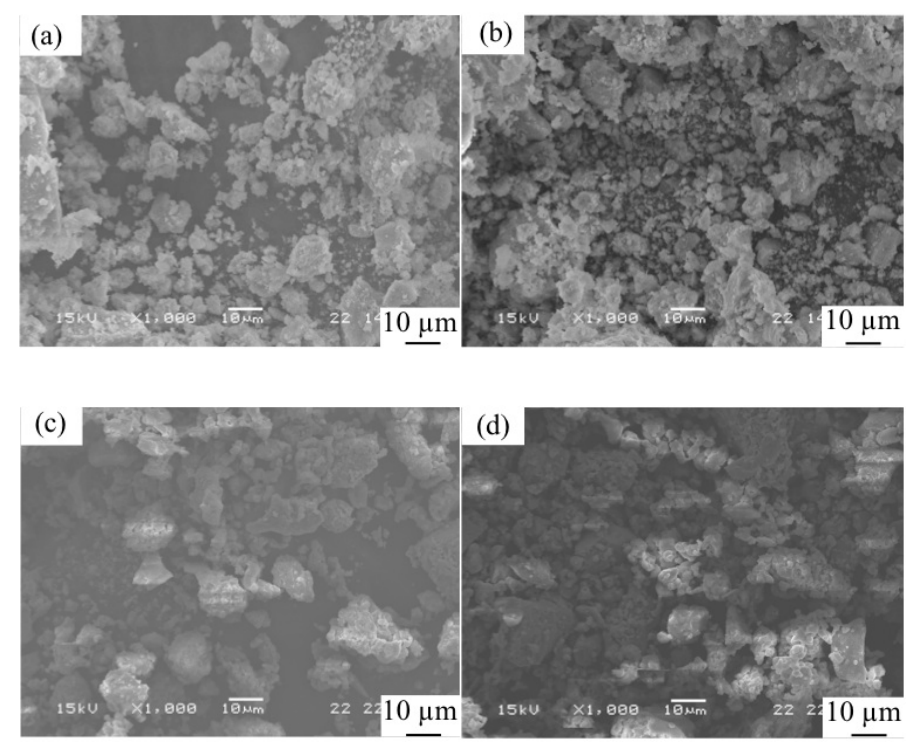

Figure 3. SEM images of samples (Eu; $5 \mathrm{~mol} \%$ ) heated at several temperatures, (a) $200^{\circ} \mathrm{C}$, (b) $400^{\circ} \mathrm{C}$, (c) $600^{\circ} \mathrm{C}$, and (d) $800^{\circ} \mathrm{C}$

\subsection{Fluorescence Properties of Phosphate Materials}

Figure 5 shows the excitation spectra of samples prepared at $5 \mathrm{~mol} \%$ of europium and then heated at several temperatures (emission, $620 \mathrm{~nm}$ ) (Hemmer et al, 2010). Samples heated at 600 and $800^{\circ} \mathrm{C}$ adsorbed strongly at $250-260 \mathrm{~nm}$ of excitation and weakly at $390-400 \mathrm{~nm}$. Amorphous phosphates indicated little adsorption at 250-260 nm. The suitable wavelength was not clear for samples heated at 200 and $400^{\circ} \mathrm{C}$. In subsequent measurements, the excitation light at $254 \mathrm{~nm}$ in wavelength was mainly used for comparison.

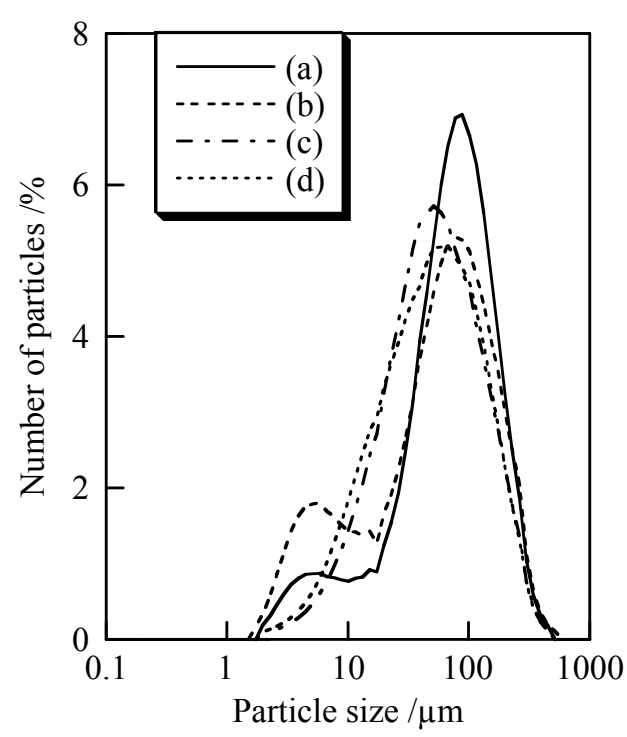

Figure 4. Particle size distribution of samples (Eu; $5 \mathrm{~mol} \%$ ) heated at several temperatures, (a) $200^{\circ} \mathrm{C}$, (b) $400^{\circ} \mathrm{C}$, (c) $600^{\circ} \mathrm{C}$, (d) $800^{\circ} \mathrm{C}$ 


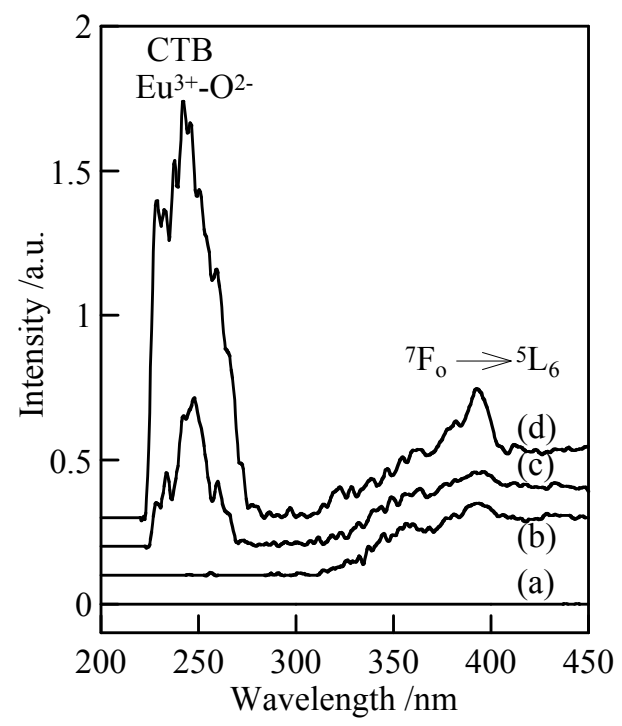

Figure 5. Excitation spectra (em. $620 \mathrm{~nm}$ ) of $5 \mathrm{~mol} \%$ Eu samples heated at several temperatures, (a) $200^{\circ} \mathrm{C}$, (b) $400^{\circ} \mathrm{C}$, (c) $600^{\circ} \mathrm{C}$, and (d) $800^{\circ} \mathrm{C}$

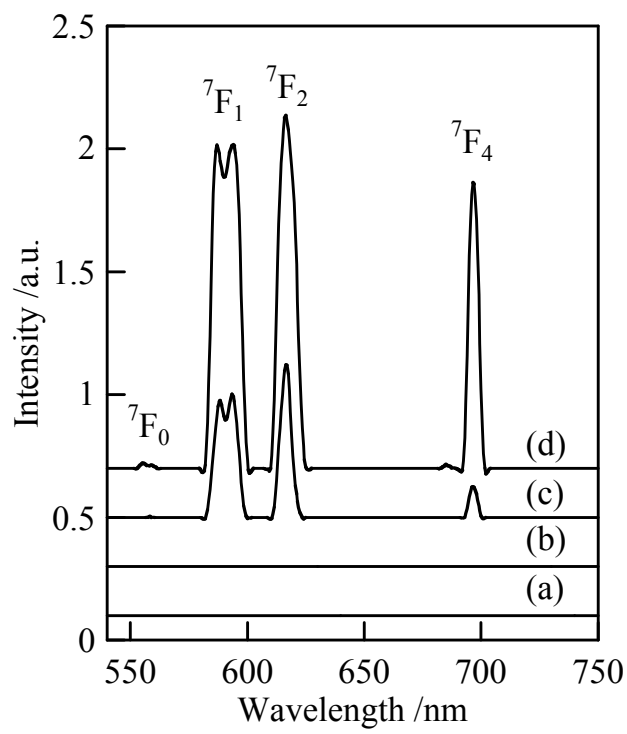

Figure 6. Emission spectra (ex. $254 \mathrm{~nm}$ ) of $5 \mathrm{~mol} \%$ Eu samples heated at several temperatures, (a) $200^{\circ} \mathrm{C}$, (b) $400^{\circ} \mathrm{C}$, (c) $600^{\circ} \mathrm{C}$, and (d) $800^{\circ} \mathrm{C}$

Figure 6 portrays the fluorescence spectra of samples prepared at $5 \mathrm{~mol} \%$ of europium and then heated at several temperatures (excitation, $254 \mathrm{~nm}$ ). Samples heated at 200 and $400^{\circ} \mathrm{C}$ had no fluorescence peak, on the other hand, samples heated at 600 and $800^{\circ} \mathrm{C}$ indicated some fluorescence peaks. These results were corresponding to the crystallization of lanthanum polyphosphate. Amorphous polyphosphate had no fluorescence peak. These results were related with little adsorption in excitation spectra (Figure 5(a) and (b)). The fluorescent peaks at 556, 590, 615 , and $690 \mathrm{~nm}$ corresponded respectively to the transition from ${ }^{5} \mathrm{D}_{0}$ to ${ }^{7} \mathrm{~F}_{0},{ }^{7} \mathrm{~F}_{1},{ }^{7} \mathrm{~F}_{2}$, and ${ }^{7} \mathrm{~F}_{4}$ (Figure 6(c) and (d)) (Zhou \& Yan, 2008). Some peaks were divided in two because of the symmetry of phosphate structure. Samples heated at $800^{\circ} \mathrm{C}$ had stronger peaks than samples heated at $600^{\circ} \mathrm{C}$.

Figure 7 shows the fluorescence peak intensity at $616 \mathrm{~nm}$ of samples prepared using various concentrations of europium (excitation, 254 and $395 \mathrm{~nm}$ ). A sample indicated a strong peak at $5 \mathrm{~mol} \%$ of europium. The peak intensity became small with the increase of the europium ratio to $10 \mathrm{~mol} \%$. In previous work, europium-substituted lanthanum polyphosphate synthesized by heating indicated a strong peak at 2 mol\% of 
europium (Onoda \& Funamoto, 2012). The optimum europium ratio was different with the synthetic process of lanthanum polyphosphate. Because it is difficult to form homogenized europium substituted lanthanum polyphosphates by solid state reaction, the fluorescence became weak at lower concentration of europium cation.

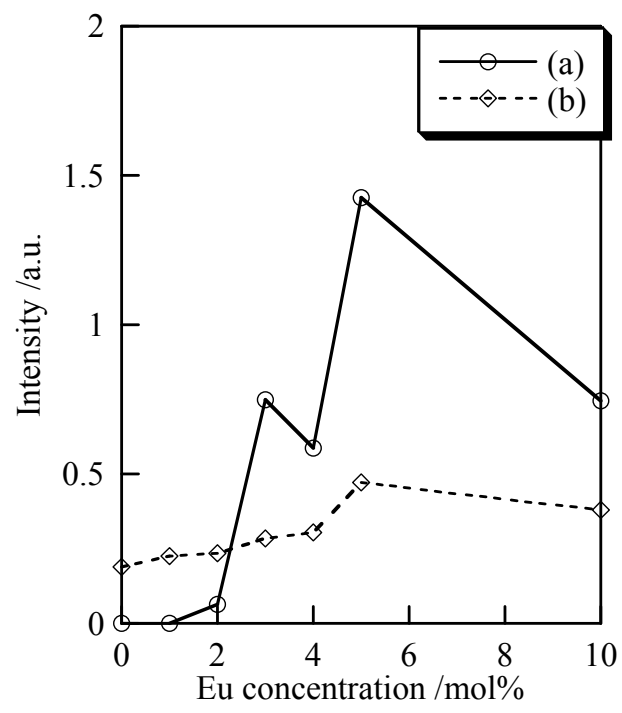

Figure 7. Emission intensity at $616 \mathrm{~nm}$ of samples prepared with various Eu concentrations and then heated at $800^{\circ} \mathrm{C}$, (a) excitation; $254 \mathrm{~nm}$, (b) $395 \mathrm{~nm}$

\section{Conclusions}

Europium-substituted lanthanum polyphosphates were synthesized from lanthanum nitrate, europium nitrate, and sodium polyphosphate solutions. The obtained samples crystallized by heating at about $600^{\circ} \mathrm{C}$. Lanthanum polyphosphates were stable from 600 to $850^{\circ} \mathrm{C}$ from TG-DTA curves. All samples in this work had no specified shape in spite of the europium ratio and heating temperatures. Samples heated at $800^{\circ} \mathrm{C}$ had strong peaks at 590 , 615 , and $690 \mathrm{~nm}$. These peaks corresponded respectively to the transition from ${ }^{5} \mathrm{D}_{0}$ to ${ }^{7} \mathrm{~F}_{1},{ }^{7} \mathrm{~F}_{2}$, and ${ }^{7} \mathrm{~F}_{4}$. Sample at $5 \mathrm{~mol} \%$ of europium-substitution indicated the strong fluorescence peaks.

\section{References}

Averbuch-Pouchat, M. T., \& Durif, A. (1996). Topics in Phosphate Chemistry. Singapore: World Scientific Publishing Co. Pte. Ltd.

Bettinelli, M., Piccinelli, F., Speghini, A., Ueda, J., \& Tanabe, S. (2012). Exited state dynamics and energy transfer rates in $\mathrm{Sr}_{3} \mathrm{~Tb}_{0.90} \mathrm{Eu}_{0.10}\left(\mathrm{PO}_{4}\right)_{3}$. Journal of Luminescence, 132(1), 27-29. http://dx.doi.org/10.1016/j.jlumin.2011.07.018

Boonchom, B., Danvirutai, C., \& Maensiri, S. (2008). Soft solution synthesis, non-isothermal decomposition kinetics and characterization of manganese dihydrogen phosphate dihydrate $\mathrm{Mn}\left(\mathrm{H}_{2} \mathrm{PO}_{4}\right)_{2} \cdot 2 \mathrm{H}_{2} \mathrm{O}$ and its thermal transformation products. Materials Chemistry and Physics, 109(2-3), 404-410. http://dx.doi.org/10.1016/j.matchemphys.2007.12.018

Briche, S., Zambon, D., Chadeyron, G., Boyer, D., Dubois, M., \& Mahiou, R. (2010). Comparison of yttrium polyphosphate $\mathrm{Y}\left(\mathrm{PO}_{3}\right)_{3}$ prepared by sol-gel process and solid state synthesis. Journal of Sol-Gel Science and Technology, 55(1), 41-51. http://dx.doi.org/10.1007/s10971-010-2211-z

Hammas, I., Horchani-Naifer, K., \& Ferid, M. (2010). Conduction properties of condensed lanthanum phosphates: $\mathrm{La}\left(\mathrm{PO}_{3}\right)_{3}$ and $\mathrm{LaP}_{5} \mathrm{O}_{14}$. Journal of Rare Earths, 28(3), 321-328. http://dx.doi.org/10.1016/S1002-0721(09)60106-X

Hemmer, E., Soga, K., Konishi, T., Watanabe, T., Taniguchi, T., \& Mathur, S. (2010). Influence of the host phase on the vibrational spectra of europium - doped zirconia prepared by hydrothermal processing. Journal of the American Ceramic Society, 93(11), 3873-3879. http://dx.doi.org/10.1111/j.1551-2916.2010.03981.x

Meiser, F., Cortez, C., \& Caruso, F. (2004). Biofunctionalization of Fluorescent Rare-Earth-Doped Lanthanum 
Phosphate Colloidal Nanoparticles. Angewandte Chemie, 43(44), 5954-5957. http://dx.doi.org/10.1002/anie.200460856

Miyajima, T., Maki, H., Kodaka, H., Ishiguro, S., Nariai, H., \& Motooka, I. (1996). ${ }^{27} \mathrm{Al}$ NMR study on the complexation of long-chain polyphosphate anioins. Phosphorus Research Bulletin, 6, 281-284. http://dx.doi.org//prb1992.6.0_281

Onoda, H., \& Funamoto, T. (2012). Synthesis and fluorescence properties of europium-substituted lanthanum orthophosphate and condensed phosphates, Advances in Materials Physics and Chemistry, 2(1), 50-54. http://dx.doi.org/10.4236/ampc.2012.21008

Onoda, H., \& Okumoto, K. (2011). Synthesis, acid and base resistance of various copper phosphate pigments by the substitution with lanthanum. Materials Science and Applications, 2(3), 208-213. http://dx.doi.org/10.4236/msa.2011.23026

Onoda, H., Inagaki, Y., Kuwabara, A., Kitamura, N., Amezawa, K., Nakahira, A., \& Tanaka, I. (2010). Synthesis and electric conductivity of bulk tetra-valent cerium pyrophosphate. Journal of Ceramic Processing Research, 11(3), 344-347. http://jcpr.kbs-lab.co.kr/file/JCPR_vol.11_2010/JCPR11-3/13[1].344-347.pdf

Onoda, H., Matsui, H., \& Tanaka, I. (2007). Improvement of acid and base resistance of nickel phosphate pigment by the addition of lanthanum cation. Materials Science and Engineering, B, 141(1-2), 28-33. http://dx.doi.org/10.1016/j.mseb.2007.05.009

Onoda, H., Nariai, H., Maki, H., \& Motooka, I. (2002). Syntheses of Various Rare Earth Phosphates from Some Rare Earth Compounds, Materials Chemistry and Physics, 73(1), 19-23. http://dx.doi.org/10.1016/S0254-0584(01)00341-8

Onoda, H., Nariai, H., Moriwaki, A., Maki, H., \& Motooka, I. (2002). Formation and Catalytic Characterization of Various Rare Earth Phosphates. Journal of Materials Chemistry, 12(6), 1754-1760. http://dx.doi.org/10.1039/b110121h

Onoda, H., Ohta, T., Tamaki, J., \& Kojima, K. (2005). Decomposition of trifluoromethane over nickel pyrophosphate catalysts containing metal cation. Applied Catalysis A; General, 288(1-2), 98-103. http://dx.doi.org/10.1016/j.apcata.2005.04.028

Onoda, H., Tange, K., \& Tanaka, I. (2008). Influence of lanthanum addition on preparation and powder properties of cobalt phosphates. Journal of Materials Science, 43(16), 5483-5488. http://dx.doi.org/10.1007/s10853-008-2831-7

Onoda, H., Taniguchi, K., \& Tanaka, I. (2008). Additional effects of urea on preparation and acidic properties of lanthanum orthophosphate. Microporous and Mesoporous Materials, 109(1-3), 193-198. http://dx.doi.org/10.1016/j.micromeso.2007.04.043

Rajesh, K., Shajesh, P., Seidei, O., Mukundan, P., \& Warrier, K. G. K. (2007). A Facile Sol-Gel strategy for the synthesis of rod-shaped nanocrystalline high-surface-area lanthanum phosphate powders and nanocoatings. Advanced Functional Materials, 17(10), 1682-1690. http://dx.doi.org/10.1002/adfm.200600794

Rathan, S. V., \& Govindaraj, G. (2010). Thermal and electrical relaxation studies in $\left.\mathrm{Li}_{(4+} x\right) \mathrm{Ti}_{x} \mathrm{Nb}_{1-x} x \mathrm{P}_{3} \mathrm{O}_{12}$ $(0.0 \leq x \leq 1.0)$ phosphate glasses. Solid State Sciences, 12(5), $730-735$. http://dx.doi.org/10.1016/j.solidstatesciences.2010.02.030

Raynaud, S., Champion, E., Bernache-Assollant, D., \& Thomas, P. (2002). Calcium phosphate apatites with variable $\mathrm{Ca} / \mathrm{P}$ atomic ratio I. Synthesis, characterization and thermal stability of powders. Biomaterials, 23(4), 1065-1072. http://dx.doi.org/10.1016/S0142-9612(01)00218-6

Shuetz, P., \& Caruso, F. (2002). Electrostatically Assembled Fluorescent Thin Films of Rare-Earth-Doped Lanthanum Phosphate Nanoparticles. Chemistry of Materials, 14(11), 4509-4516. http://dx.doi.org/10.1021/cm0212257

Zhou, L., \& Yan, B. (2008). Sol-gel synthesis and photoluminescence of $\mathrm{CaSiO}_{3}: \mathrm{Eu}^{3+}$ nanophosphors using novel silicate sources. Journal of Physics and Chemistry of Solids, 69(11), 2877-2882. http://dx.doi.org/10.1016/j.jpcs.2008.07.012 